90(b). LH

Draft

Published First Things 141 (March, 2004): 29-34

\title{
Adams v. Jefferson: The Freedom of Public Religion
}

\author{
John Witte, Jr.
}

\begin{abstract}
While Thomas Jefferson's theory of strict separation of church and state has long captured the $20^{\text {th }}$ century constitutional and cultural imagination, it was his friendly rival John Adams' theory of the freedom of both private and public religion that dominated American life until the 1940 s and is returning to prominence in recent United States Supreme Court cases. This latter view is manifest in the historical and recent cooperation of church and state and in the recent First Amendment accommodation of all public expressions of peaceable religions.

Keywords: John Adams, Thomas Jefferson, religious freedom, religious establishment, church-state relations, First Amendment, establishment clause, wall of separation, state funding of religion, public schools, religion and education
\end{abstract}

The civic catechisms and canticles of our day still celebrate Thomas Jefferson's experiment in religious liberty. To end a millennium of repressive religious establishments, we are taught, Jefferson sought liberty in the twin formulas of privatizing religion and secularizing politics. Religion must be "a concern purely between our God and our consciences," he wrote. Politics must be conducted with "a wall of separation between church and state." "Public Religion" is a threat to private religion, and must thus be discouraged. "Political ministry" is a menace to political integrity and must thus be outlawed.

These Jeffersonian maxims remain for many today the cardinal axioms of a unique American logic of religious freedom to which every patriotic individual and institution should yield. Every public school student learns the virtues of keeping his Bible at home and her prayers in the closet. Every church knows the tax law advantages of high cultural conformity and low political temperature. Every politician understands the 
calculus of courting religious favors without subvening religious causes. Religious privatization is the bargain we must strike to attain religious freedom for all. A wall of separation is the barrier we must build to contain religious bigotry for good. If only those right-wing killjoys of our day would learn proper patriotism, instead of pestering us with their Decalogues and faith-based initiatives!

"A page of history is worth a volume of logic," Justice Holmes once said. And careful historical work in the past two decades has begun to call a good deal of this popular Jeffersonian logic into question. Not only are Jefferson's views on disestablishment and free exercise considerably more delphic than was once imagined. But the fuller account now available of the genesis and exodus of the American experiment in religious liberty suggests that Jefferson's views were hardly conventional in his own day or in the century to follow. Indeed, the Jeffersonian model of religious liberty came to constitutional prominence only in the 1940s, and then largely at the behest of the United States Supreme Court. During much of the time before that, the American experiment was devoted not so much to privatizing religion and to secularizing politics, as to balancing the freedoms of all private religions against the establishment of one public religion.

The implications of these new historical insights have only begun to be worked out. The hard religious right has woven these historical insights into a crusade to reclaim the nation's Christian roots and to reestablish its Christian traditions in place of the establishment of secularism that they now see. The hard religious left has converted them into a new appreciation for the bold prescience of the United States Supreme Court to anticipate the needs of our fragmented postmodern and post-Christian polity. What seems to be lost on both the hard right and the hard left is that the Supreme Court itself has quietly abandoned much of its earlier separationist logic in recent years, and moved gradually toward the recognition that both private and public forms of religion deserve constitutional freedom.

To relate this historical story and its modern implications a bit more fully, permit me to revisit Jefferson's model of religious liberty, now viewed in juxtaposition with the model of religious liberty developed by John Adams, his life-long friendly rival. I shall then draw out some of the enduring lessons that these two founding models of religious liberty teach us, and how they can be used to reinterpret several recent Supreme Court cases.

As our civic catechism has taught us, Thomas Jefferson did regard his 1779 Bill for the Establishment of Religious Freedom in Virginia as a "fair" and "novel experiment." This law, declared Jefferson, defied the 
ancient assumptions of the West: that one form of Christianity must be established in a community, and that the state must protect and support it against all other religions. Virginia would no longer suffer such state prescriptions or proscriptions of religion. All forms of Christianity must now stand on their own feet and on an equal footing with the faiths of "the Jew and the Gentile, ... the Mahometan, the Hindu, and [the] Infidel of every denomination." Their survival and growth must turn on the cogency of their word, not the coercion of the sword, on the faith of their members, not the force of the law.

True religious liberty, Jefferson argued, requires both the free exercise and the disestablishment of religion. On the one hand, the state should protect the liberty of conscience and free exercise of all its subjects--however impious or impish their religious beliefs and customs might appear. "Almighty God hath created the mind free," Jefferson wrote, and thus "no man shall be compelled to frequent or support any religious worship, place, or ministry whatsoever, nor shall be enforced, restrained, molested, or burthened in his body or goods, nor shall otherwise suffer on account of his religious opinions or belief; but that all men shall be free to profess, and by argument to maintain, their opinion in matters of religion, and that the same shall in no wise diminish, enlarge, or affect their civil capacities."

On the other hand, the state should disestablish all religion. The state should not give special aid, support, privilege, or protection to religious doctrines or groups--through special tax appropriations and exemptions, special donations of goods and realty, or special laws of incorporation and criminal protection. The state should not direct its laws to religious purposes. The state should not draw on the services of religious associations, nor seek to interfere in their order, organization, or orthodoxy. As Jefferson put it in his famous 1802 letter to the Danbury Baptist Association: "Believing with you that religion is a matter which lies solely between a man and his God, that he owes account to none other for his faith or his worship, that the legislative powers of government reach actions only, and not opinions, I contemplate ... a wall of separation between church and State."

Clergy were to respect this wall of separation as much as politicians. Clergy needed to stick to their specialty of soulcraft rather than interfere in the specialty of statecraft. Religion is merely "a separate department of knowledge," Jefferson wrote, alongside other specialized disciplines like physics, biology, law, politics, and medicine. Preachers are the specialists in religion, and are hired to devote their time and energy to this specialty. "Whenever, therefore, preachers, instead of a lesson in religion, put them off with a discourse on the Copernican system, on chemical affinities, on the construction of government, or the 
characters of those administering it, it is a breach of contract, depriving their audience of the kind of service for which they were salaried."

At precisely the same time that Jefferson was at work defending his 1779 Bill for the Establishment of Religious Freedom for Virginia, John Adams was at work drafting the Massachusetts Constitution. "It can no longer be called in question," he wrote, that "authority in magistrates and obedience of citizens can be grounded on reason, morality, and the Christian religion," without succumbing to "the monkery of priests or the knavery of politicians." It also can no longer be called into question that peace and justice require the state to guarantee religious liberty to all. The best constitutional formula to attain these two goals, Adams concluded, is for the state to balance the freedom of many private religions with the establishment of one public religion.

On the one hand, every society must protect a plurality of peaceable private religions--whose rights are limited only by the parallel rights of juxtaposed religions and the duties of the established public religion. The notion that a state could coerce all persons into adherence and adherents to a common public religion alone was for Adams a philosophical fiction. Persons would make their own private judgments in matters of faith. Any attempt to coerce their consciences would only breed hypocrisy and resentment.

Moreover, the maintenance of religious plurality was essential for the protection of civil society and civil liberties. "Checks and balances, Jefferson," Adams later wrote to his friend in Monticello, in the political as well as the religious sphere "are our only Security, for the progress of Mind, as well as the Security of Body. Every Species of Christians would persecute Deists, as either Sect would persecute another, if it had unchecked and unballanced Power. Nay, the Deists would persecute Christians, and Atheists would persecute Deists, with as unrelenting Cruelty, as any Christians would persecute them or one another. Know thyself, Human nature!"

On the other hand, every society must establish by law some form of public religion, some image and ideal of itself, some common values and beliefs to undergird and support the plurality of protected private religions. The notion that a state could remain neutral and purged of any public religion was, for Adams, equally a philosophical fiction. Absent a commonly adopted set of values and beliefs, politicians would invariably hold out their private convictions as public ones. It was thus essential for each community to define and defend the basics of a public religion. In Adams's view, its creed was honesty, diligence, devotion, obedience, virtue, and love of God, neighbor, and self. Its icons were the Bible, the bells of liberty, the memorials of patriots, the constitution. Its clergy were 
public-spirited ministers and religiously-committed politicians. Its liturgy was the public proclamation of oaths, prayers, songs, and election and Thanksgiving Day sermons. Its policy was state appointment of chaplains for the legislature, military, and prison, state sanctions against blasphemy, sacrilege, and iconoclasm, state administration of tithe collections, test oaths, and clerical appointments, state sponsorship of religious societies, schools, and charities. "Statesmen may plan and speculate for liberty," Adams wrote in defense of his views, "but it is religion and morality alone which can establish the principles upon which freedom can securely stand." A "Publick Religion" sets "the foundation, not only of republicanism and of all free government, but of social felicity under all governments and in all the combinations of human society."

Following Adams' views, the Massachusetts Constitution of 1780 struck this balance between the freedom of peaceable private religions and the establishment of one public religion. Article II provided: "It is the right as well as the duty of all men in society, publickly, and at stated seasons to worship the SUPREME BEING, the great Creator and preserver of the Universe." Article III stated the reason: "the public worship of GOD and instructions in piety, religion, and morality ... promote their happiness, and secure ... the good order and preservation of their government." The same constitution also insisted that all persons, particularly political leaders, maintain rigorous moral and religious standards, which they confirmed in their oaths of office. It also rendered these same moral qualities essential ingredients of education within the state, since "the encouragement of arts and sciences, and all good literature, tends to the honor of GOD, the advantage of the Christian religion, and the great benefit of this and the other United States of America."

Here are two models of religious liberty offered by two of the greatest luminaries of the American founding era. There were many other models available in their day--some more theological, some more philosophical in tone. But these two models, given the eminence of their authors and the importance of their home states of Virginia and Massachusetts, were of central importance.

Both Jefferson and Adams were self-consciously engaged in a new experiment in religious liberty. Both started with the credo of the American Declaration of Independence which they drafted: that "all men are created equal" and that they have "certain unalienable rights." Both understood that religion is special and must be accorded special constitutional protection. Both understood that religion is more than simply a peculiar form of speech, press, and assembly, but deserves it own separate constitutional guarantees. Religion is a unique source of individual and personal identity, involving "duties that we owe to our Creator, and the 
manner of discharging them," as their compatriot James Madison put it. Religion is also a unique form of public and social identity, involving a vast plurality of sanctuaries, schools, charities, missions, and other forms and forums of faith. Both individual and corporate, private and public entities and exercises of religion -- in all their self-defined varieties -- properly deserve constitutional protection.

So much was common between them. But while Jefferson advocated a robust freedom of exercise, Adams condoned only a "tempered" religious freedom. While Jefferson urged the separation of church and state, Adams urged only a division of religious and political offices. While Jefferson advocated the disestablishment of all religions, Adams insisted on the "mild and equitable" establishment of one public religion.

For Jefferson, to establish one public religion was to threaten all private religions. To encourage religious uniformity was to jeopardize religious sincerity. To limit religious exercise was to stymie religious development. To enlist the church's ministry was to impugn the state's integrity. Religion was thus best left to the private sphere and sanctuary; church and state were best left separated from each other.

Adams agreed that too little religious freedom was a recipe for hypocrisy and impiety. But too much religious freedom, he argued, was an invitation to depravity and license. Too firm a religious establishment would certainly breed coercion and corruption. But too little a religious establishment would convert private prejudices into constitutional prerogatives. Somewhere between these extremes a society must strike its balance.

It is well known that the United States Supreme Court chose to apply Jefferson's model of religious liberty in its early interpretation of the First Amendment. In the landmark case of Everson v. Board of Education (1947), the United States Supreme Court for the first time used the First Amendment prohibition on religious establishment to declare local laws unconstitutional. The Court also read Jefferson's call for "a wall of separation between church and state" as the essential meaning and mandate of the First Amendment. In more than 30 cases from 1947 to 1985, the Court used this separationist logic to purge public schools of their traditional religious teachings and practices and cut religious schools from their traditional state patronage and preferences. Following these precedents, lower courts struck down many other traditional forms of state protection, participation, and patronage of religion.

It is less well known that over the past two decades, the Court has abandoned much of its earlier separationism, and reversed several of its 
harshest cases on point. While it has not yet crafted a consistent or coherent new First Amendment logic, the Court seems intent on developing a new model of religious liberty that draws on the insights of both Jefferson and Adams - but rejects their respective calls for the privatization or the establishment of religion. The Supreme Court formula that has begun to emerge is that both private and public forms of religion deserve constitutional freedom and support, though neither may be established nor preferred.

Tradition is one strong vector in some of the Court's recent First Amendment cases. The Court had used arguments from tradition a few times before, as part of broader rationales for upholding religious tax exemptions and Sabbath Day laws. But in Marsh v. Chambers (1983), the argument from tradition became the exclusive basis on which the Court upheld a state legislature's practice of funding a chaplain and opening its sessions with his prayers. Lower courts had found this practice patently unconstitutional under the Court's then prevailing separationist precedents. Writing for the Court, Chief Justice Burger defended such practices as a noble survival of the traditional public role of religion in American life and law: "In light of the unambiguous and unbroken history of more than 200 years, there can be no doubt that the practice of opening legislative sessions with prayer has become part of the fabric of our society. To invoke Divine guidance on a public body entrusted with making the laws is not, in these circumstances, an 'establishment' of religion [but] simply a tolerable acknowledgement of beliefs widely held among the people of this country.... '[W]e are a religious people whose institutions presuppose a Supreme Being'."

Arguments from tradition, while by themselves rarely convincing, can sometimes bolster a broader rationale for upholding traditional features of a public religion and a religious public. Tradition can sometimes serve effectively as something of a null hypothesis--to be overcome by strong constitutional arguments rather than discarded by simple invocations of principle. As Justice Holmes once put it: "If a thing has been practised for two hundred years by common consent, it will need a strong case for the Fourteenth Amendment to affect it." Innocuous longstanding practices, therefore, such as religious tax exemptions, military chaplains, prison prayer books, and public displays of Decalogues and of other religious symbols might well be justified.

There are limits and dangers to arguments from tradition, which the Court itself betrayed the following year. In Lynch v. Donnelly (1984) the Court upheld a municipality's traditional practice of maintaining a manger scene (a crèche) on a public park as part of a large holiday display in a downtown shopping area. "There is an unbroken history of official acknowledgment by all three branches of government of the role of 
religion in American life," Chief Justice Burger wrote, repeating his Marsh argument and now giving an ample list of illustrations.

There is another reason to uphold this display, however, the Chief Justice continued. Crèches, while of undoubted religious significance to Christians, are merely "passive" parts of "purely secular displays extant at Christmas." They "engender a friendly community spirit of good will" that "brings people into the central city and serves commercial interests and benefits merchants." The prayers that are occasionally offered at the crèche, Justice O'Connor wrote in concurrence, merely "solemnize public occasions, express confidence in the future, and encourage the recognition of what is worthy of appreciation in society." Governmental participation in and support of such "ceremonial deism," the Court concluded, cannot be assessed by "mechanical logic" or "absolutist tests" of establishment. "It is far too late in the day to impose a crabbed reading of the [Establishment] Clause on the country."

A crabbed reading of establishment would have been better than such a crass rendering of religion. For the Court to suggest that crèches are mere advertisements, prayers mere ceremony, and piety mere nostalgia is to create an empty "American Shinto"--a public religion that is perhaps purged enough of its confessional identity to pass constitutional muster, but too bleached and too bland to be religiously efficacious, let alone civilly effective.

Arguments from tradition, while helpful, are thus inherently limited in their ability to define and defend the public place of religion today. Such arguments perforce assume a traditional definition of what a public religion is--namely, a common system of beliefs, values, and practices drawn eclectically from the multiple denominations within a community. In the religiously homogeneous environment of John Adams' day, a public religion of the common denominator and common denomination still had the doctrinal rigor, liturgical specificity, and moral suasion to be effective. In the religiously heterogeneous environment of our day--with more than 1,000 incorporated denominations on the books--no such effective common religion can be readily devised or defended.

More recent cases suggest a budding new way of defining and defending the legal place of public religion. The Court has numerous times upheld government policies that support the public access and activities of religious individuals and groups--so long as these religious parties act voluntarily, and so long as non-religious parties also benefit from the same government support. Under this logic, Christian clergy were just as entitled to run for state political office as non-religious candidates. Church-affiliated pregnancy counseling centers could be funded as part of a broader federal family counseling program. Religious 
student groups could have equal access to state university and public school classrooms that were open to non-religious student groups.

Religious school students were just as entitled to avail themselves of general scholarships, remedial, and disability services as public school students. Religious groups were given equal access to public facilities or civic education programs that were already opened to other civic groups. Religious parties were just as entitled as non-religious parties to display their symbols in public forums. Religious student newspapers were just as entitled to public university funding as those of non-religious student groups. Religious schools were just as entitled as other private schools to participate in a state-sponsored educational improvement or school voucher or educational program.

These holdings were defended on wide-ranging constitutional grounds--as a proper accommodation of religion under the establishment clause, as a necessary protection of religion under the free speech or free exercise clauses, as a simple application of the equal protection clause, among other arguments.

One theme common to many of these cases, however, is that public religion must be as free as private religion. Not because the religious groups in these cases are really non-religious. Not because their public activities are really non-sectarian. And not because their public expressions are really part of the cultural mainstream. To the contrary, these public groups and activities deserve to be free, just because they are religious, just because they engage in sectarian practices, just because they sometimes take their stands above, beyond, and against the mainstream. They provide leaven and leverage for the polity to improve.

A second theme common to these cases is that the freedom of public religion sometimes requires the support of the state. Today's state is not the distant, quiet sovereign of Jefferson's day from whom separation was both natural and easy. Today's modern welfare state, whether for good or ill, is an intensely active sovereign from whom complete separation is impossible. Few religious bodies can now avoid contact with the state's pervasive network of education, charity, welfare, child care, health care, family, construction, zoning, workplace, taxation, security and other regulations. Both confrontation and cooperation with the modern welfare state are almost inevitable for any religion. When a state's regulation imposes too heavy a burden on a particular religion, the free exercise clause should provide a pathway to relief. When a state's appropriation imparts too generous a benefit to religion alone, the establishment clause should provide a pathway to dissent. But when a general government scheme provides public religious groups and activities with the same benefits afforded to all other eligible recipients, disestablishment clause objections are not only "crabbed" but corrosive. 
A third theme common to these cases is that a public religion cannot be a common religion. If the religious gerrymandering of Lynch $v$. Donnelly and its progeny had not already made this clear, these more recent cases underscore the point. Today, our public religion must be a collection of particular religions, not the combination of religious particulars. It must be a process of open religious discourse, not a product of ecumenical distillation. All religious voices, visions, and values must be heard and deliberated in the public square. All public religious services and activities, unless criminal or tortious, must be given a chance to come forth and compete, in all their denominational particularity.

Some conservative Evangelical and Catholic groups today have seen and seized on this insight better than most. Their rise to prominence in the public square in recent years should not be met with glib talk of censorship or habitual incantation of Jefferson's mythical wall of separation. The rise of the so-called Christian right should be met with the equally strong rise of the Christian left, of the Christian middle, and of many other Jewish, Muslim, and other religious groups who test and contest its premises, prescriptions, and policies. That is how a healthy democracy works. The real challenge of the new Christian right is not to the integrity of American politics but to the apathy of American religions. It is a challenge for peoples of all faith and of no faiths to take their place in the marketplace.

A fourth teaching of these cases is that freedom of public religion also requires freedom from public religion. Government must strike a balance between coercion and freedom. The state cannot coerce citizens to participate in religious ceremonies and subsidies that they find odious. But the state cannot prevent citizens from participation in public ceremonies and programs just because they are religious. It is one thing to outlaw Christian prayers and broadcasted Bible readings from the public school; after all, students are compelled to be there. It is quite another thing to ban moments of silence and private religious speech in these same public schools. It is one thing to bar direct tax support for religious education, quite another thing to bar tax deductions for parents who choose to educate their children in religious schools. It is one thing to prevent government officials from delegating their core police powers to religious bodies, quite another thing to prevent them from facilitating the charitable services of voluntary religious and non-religious associations alike. It is one thing to outlaw governmental prescriptions of prayers, ceremonies, and symbols in public forums, quite another thing to outlaw governmental accommodations of private prayers, ceremonies, and symbols in these same public forums.

Individuals should exercise a comparable prudence in seeking protection from public religion. In the public religion schemes of 
nineteenth-century America, it was not so much the courts as the frontier that provided this freedom--a place away from it all, where one could escape with one's conscience and co-religionists. Today, the frontier still provides this freedom--if not physically in small towns and wild mountains, then virtually in our ability to sift out and shut out the public voices of religion that we do not wish to hear.

Both modern technology and modern privacy make escape to the frontier considerably easier than in the days of covered wagons and mule trains. Just turn off CBN. Turn away the missionary at your door. Close your eyes to the city crucifix that offends. Cover your ears to the public prayer that you can't abide. Forgo the military chaplain's pastoral counseling. Skip the legislative chaplain's prayers. Walk by the town hall's menorah and star. Don't read the Decalogue behind the judge. Don't join the religious student group. Don't vote for the collared candidate. Don't browse the Evangelicals' newspapers. Avoid the services of the Catholic counselors. Shun the readings of the Scientologists. Turn down the trinkets of the colporteurs. Turn back the ministries of the hate-mongers. All these escapes to the virtual frontier, the law does and will protect -- with force if necessary. Such voluntary self-protections from religion will ultimately provide far greater religious freedom for all than pressing yet another tired constitutional case. 